\title{
Moderating role of firms' rank in ASEAN corporate governance scorecard on effect of foreign ownership on firm value
}

\author{
Dormauli Justina', Alex Johanes Simamora ${ }^{2}$ \\ 'STIM Amkop Palembang, Talangratu KM 5, Palembang 30128, Indonesia \\ Corresponding author e-mail: justina dee@yahoo.com \\ ${ }^{2}$ Independent Researcher, Jalan Perumnas Gang Serayu Blok D 29B, Perum Condongsari, \\ Depok, Sleman, Yogyakarta 55283, Indonesia \\ e-mail: alexjohanessimamora@gmail.com
}

\begin{abstract}
This research is aimed to examine moderating role of firms' rank in ASEAN corporate governance scorecard on effect of foreign ownership on firm value in ASEAN. Research sample consists of 491 manufacture firms listed in stock market of Thailand, Singapore, Philippines, Indonesia, and Malaysia from 2012-2013. With regression analysis, this research finds that big 50 of highest ASEAN corporate governance scorecard rank moderates effect of foreign ownership on firm value in ASEAN. High ASEAN corporate governance scorecard; as improvement of rights of shareholders, equitable treatment of shareholders, role of stakeholders, disclosure and transparency, responsibilities of the board; supports foreign shareholder role in firm value increasing. Management could make firm policy about optimal foreign ownership structure as well as optimal corporate governance, so management could maximizes shareholders wealth by firm value increasing. Investors, who have interest send their investment abroad especially in ASEAN, have to see condition of corporate governance, so investors' wealth could be maximized.
\end{abstract}

Keywords: ASEAN corporate governance scorecard, foreign ownership, firm value.

\begin{abstract}
Abstrak
Penelitian ini bertujuan untuk menguji peringkat perusahaan berdasarkan ASEAN corporate governance scorecard, sebagai variabel pemoderasi, atas pengaruh kepemilikan asing terhadap nilai perusahaan di ASEAN. Sample penelitian terdiri dari 491 perusahaan manufaktur yang terdaftar di pasar modal Thailand, Singapore, Philippines, Indonesia, and Malaysia tahun 2012-2013. Dengan analisis white-regression, penelitian ini menemukan bahwa peringkat 50 tertinggi ASEAN corporate governance scorecard memoderasi pengaruh kepemilikan asing terhadap nilai perusahaan. Skor tinggi ASEAN corporate governance scorecard; sebagai peningkatan hak pemegang saham, kesetaran pemegang saham, peran pemangku kepentingan, pengungkapan dan transparansi, serta tanggung jawab dewan; meningkatkan peran pemegang saham asing dalam meningkatkan nilai perusahaan. Manajemen dapat membuat kebijakan mengenai kepemilikan asing juga corporate governance yang optimal, sehingga manajemen dapat meningkatkan kesejahteraan pemegang saham melalui peningkatan nilai perusahaan. Investor yang tertarik berinvestasi di luar negeri, khususnya di ASEAN, harus memperhatikan kondisi corporate governance perusahaan, sehingga kesejahteraan investor dapat meningkat.
\end{abstract}

Kata Kunci: ASEAN corporate governance scorecard, kepemilikan asing, nilai perusahaan.

JEL: G30, G34, G38, G39

DOI: $10.20885 /$ jsb.vol21.iss2.art4

\section{Introduction}

In terms of financial management, a firm established to increase wealth of the owner or shareholders through increasing of firm value (Kesten, 2010). When firm value is high, wealth of shareholders is high as well. If firm which its shares are traded in stock exchange, then stock price is an indicator of the firm value. Stock price is an overview of various decisions and policies that made by the management, so that firm value is result of management action (Kesten, 2010). 
Agency conflict is one of the problems that hinder the value enhancement. Agency conflict exists because there is conflict of interest between shareholders and management (Chen, Lu, \& Sougiannis, 2012; Gilson \& Whitehead, 2008; Renders \& Gaeremynck, 2012). Management that have bigger power than shareholder, will decreases firm value because management will act based on their own interests (J. Lee, Park, \& Park, 2015). Management is less likely to works with consideration of shareholders wealth. In order to minimize agency conflict, shareholders have to do management monitoring, so management will less likely act based on their own interests and more likely act based on shareholders wealth and firm value increasing. Previous researches have proved that share ownership factors could decrease agency conflict by information asymmetric minimizing (Shiri, Salehi, \& Radbon, 2016), financing cost minimizing (Tan \& Ma, 2016), and firm value maximizing (Cheung, Stouraitis, \& Tan, 2011; Wei, Xie, \& Zhang, 2005).

One type of share ownerships is foreign ownership. Foreign ownership is shares owned by shareholders of firm from across country. Foreign ownership caused by shares trading in capital market by individual or institutional investor, or establishment of subsidiary by home country's firm (origin of foreign shareholders) as foreign or multinational firm in host country (country where foreign shareholders doing investment). Foreign shareholders could increase firm value (Wei et al., 2005). Foreign shareholders, as individual or institutional shareholders, have specific financial and business characteristic. The specific financial and business characteristic is international diversification of earnings that could decrease the variability of cash flows and bankruptcy costs than domestic shareholders (Gurunlu \& Gursoy, 2010). Foreign shareholders could establish new channel of market share and funding resources across country (Gurunlu \& Gursoy, 2010). Foreign shareholders have more business information; especially information of foreign customer, condition of stock market and debt market, as well as banking loans in home country; than domestic shareholders. Foreign shareholders could make management to diversify market share by sells their product to another countries, and generates more earnings as well as decrease the variability of cash flows from sales if product sales in domestic market have high uncertainty. Foreign shareholders give more option of funding resources as well. Foreign shareholders could raises fund in low cost of capital and low risk from another investor and creditors from another countries, and prevent management to increases domestic debt (Gurunlu \& Gursoy, 2010) if cost of domestic debt is high. When risk and cost of debt is high, foreign shareholders will decreases debt and tends to use retained earnings as internal funding resource and leads to decreasing of potential debt payment failure (Gurunlu \& Gursoy, 2010). By decreasing of variability of cash flows and potential debt payment failure, foreign shareholders could reduce bankruptcy costs. By makes decision of new market and low risk financing policies in shareholders general meeting, foreign shareholder could increases firm value.

In case of foreign or multinational firm in host country, foreign firm owned by firm from home country could be categorized as firm owned by foreign institutional shareholders (Rasiah \& Malakolunthu, 2009). Foreign institutional shareholders could own domestic firm. As foreign institutional shareholders, home country's firm implements higher labor productivity, wages and export intensity than local institutional shareholders, through technological intensities, based on standard business activities in home country (Rasiah \& Malakolunthu, 2009). Foreign shareholders have better monitoring of management as well, than domestic shareholders, because foreign shareholders is more independent (Ahmed \& Iwasaki, 2015).

In the other hand, foreign ownership could decrease firm value. Foreign shareholders do not really attach to the firm, because they have international investment channels, so foreign shareholders have shorter term relationship to the firm than domestic shareholders (Kim, 2011). In addition, Kim (2011) stated that firm's share will be more volatiles in stock market because foreign shareholders have short term relationship to the firm. Foreign ownership leads to bigger cost of foreign capital structure (Eun \& Janakiramanan, 1998). Big cost of foreign capital structure comes from additional cost of foreign ownership restriction in host country (Eun \& Janakiramanan, 1998). Lam (1997) stated that if deadweight cost of foreign shareholders in home country is high, then host 
country will restricts foreign ownership, so shares held by foreign shareholders have premium price compares to shares held by local shareholders. Restrictions of foreign ownership is aimed to avoid decreasing of domestic return firm because of resources transferring from host country (Yean \& Das, 2015). Foreign ownership could improve information asymmetric as well, because of differences of language and geographical aspects between home country and host country.

It is important to analyze foreign ownership because the rapid globalization of financial markets in recent years has been accompanied by a growing number of firms raising capital across countries (Bell, Filatotchev, \& Aguilera, 2014). In China, external opening market of import makes foreign direct investment increases (Zhang \& Roelfsema, 2014), such as acquisition of assets (Lau \& Bruton, 2008).

Foreign ownership is one of the most important factors that affect firm value when ownership of firm's shares owned across country. In agency theory, Jensen \& Meckling (1976) suggest benefit of shareholders with large ownership have strong incentives to monitors manager, thus mitigates agency conflict, that help to maximize their firm value. In the context of increased globalization of capital markets, many countries, includes Association of South East Asian Nation (ASEAN) countries, gradually opened up their capital market to attract foreign investor. Evidences of globalization such as growing of number of firms that raises capital abroad by initial public offering (IPO) of foreign firm in United State (Bell et al., 2014), and increasing of foreign direct investment in China (Zhang \& Roelfsema, 2014). As a result, foreign ownership is not only contributes to the development of capital market or economic development of countries, but also become important factor in ownership structure system. Implementation of agency theory in increased globalization of capital markets perspective shows that foreign shareholders, potentially, could have large ownership; and hold the role of manager monitoring to mitigates agency conflict and maximize firm value. Recent researches have showed effect of foreign shareholders on firm value as consequences of increased of globalization across countries. Chari, Chen, \& Dominguez (2012) found that foreign ownership increases firm value by increasing of profitability and stock market price. Ahmed \& Iwasaki (2015) found foreign shareholders increases firm value by having better monitoring of management because foreign shareholders is more independent than domestic shareholders.

ASEAN countries have been affected by globalization as well. ASEAN countries have established ASEAN Economics Community (AEC), and it is believed that in 2015, ASEAN borders will be fully open to allow free flows of capital and labor across country's borders (Nikomborirak, 2015), including of stock market integration (G. Lee \& Jeong, 2016). Less barriers of capital market between ASEAN countries will increases foreign investment and capital as well. Based on data accessed in World Bank (2016a), there is increasing of foreign direct investments in ASEAN countries from 2012 to 2013, for Indonesia 10 percent, Malaysia 27 percent, Philippines 16 percent, Singapore 16 percent, Thailand 24 percent.

Inconsistency of foreign ownership effects on firm value depends on condition of corporate governance. Corporate governance as an internal system encompasses policies, processes, and people that serve the needs of shareholders and other stakeholders by directing and controlling management activities based on good business practices, objectivity, and integrity (Man \& Wong, 2013). Good corporate governance is needed because of the existence of agency conflict that caused by the separation of ownership of resources and managing those resources (Jensen \& Meckling, 1976), and because of shareholders protection from expropriation by management (Madhani, 2016). As the owner, foreign shareholders could not maximize their role to increases firm competitive advantage because foreign shareholders do not directly involves in daily activities of firm, so foreign shareholders need good corporate governance implementation to have good firm competitive advantage. Good corporate governance improves role of foreign ownership. If corporate governance supports foreign ownership role, then foreign ownership will increases firm value (Viana, Sheng, \& Lora, 2010). Corporate governance that could support role of shareholders such as strong external marketplace commitment and legislation, as well as strong shareholders protection, 
and a healthy board culture that safeguards policies and processes (Man \& Wong, 2013). Maher \& Andersson (1999) stated that corporate governance tends to foster a more open and equitable distribution of information and place a stronger emphasis on the protection of shareholders rights, in particular, those of minority investors. Since foreign shareholders do not directly involves in daily activities of management; then this research will examine whether foreign shareholders protection, other stakeholders monitoring, healthy board culture, and transparency help the role of foreign ownership to performs good competitive advantage that have been brought by foreign shareholders in daily activities of management, so it can leads to firm value increasing.

The corporate governance structure specifies the distribution of rights and responsibilities among different stakeholders in the system, such as the board, managers, shareholders and spells out the rules and procedures for making decisions on corporate affairs (Madhani, 2016). Further, Madhani (2016) added that corporate governance provides an ethical process as well as welldefined structure through which the objectives of the firm, the means of attaining such objectives, and systems of monitoring performance are also set. Corporate governance in stock market could be seen as corporate governance mechanism by political and legal structure, public monitoring (Forti, Tsang, \& Peixoto, 2011), investor protections and public policy making (Guillen \& Capron, 2016) to increases firm market value.

ASEAN Capital Market Forum (2015) introduce ASEAN corporate governance scorecard as assessment of corporate governance of all listed firms of capital markets in countries of ASEAN. It shows corporate governance practices covers area of rights of shareholders, equitable treatment of shareholders, role of stakeholders, disclosure and transparency, responsibilities of the board (ASEAN-Capital-Market-Forum, 2015). It is important to examine corporate governance in ASEAN, because firms in ASEAN nations have operated in environment where government policies were lacking and the market structure was underdeveloped (Liu, 2016), at the same time, ASEAN will be a powerful market by representing the third largest economic cooperation following the North America Free Trade Agreement (NAFTA) and the Europe Union (EU) (G. Lee \& Jeong, 2016). Objective of this research is to examine moderating role of corporate governance on effect of foreign ownership on firm value in ASEAN countries.

\section{Literature Review}

\section{ASEAN Economics Community (AEC)}

ASEAN consists of ten diverse economies, ranging from Singapore, with GDP per capita at nominal value of US\$55,182 (ranked 8th of 183 countries in the world in 2013) to Cambodia with GDP per capita at nominal value of US\$1,028 (ranked 156th) (Nikomborirak, 2015). ASEAN has come a long way in reducing barriers to trade in goods among member countries since the creation of the ASEAN Free Trade Area Agreement, signed in 1993 (Nikomborirak, 2015), and have been made blueprint of ASEAN Economics Community (AEC) in 2007 with goal level about 90.5 percent in 2015 (Yean \& Das, 2015). The Blueprint consists of four key pillars: (1) a single market and production base; (2) a highly competitive economic region; (4) a region of equitable economic development; and (5) a region fully integrated into the global economy (Nikomborirak, 2015). AEC could produce gains similar to those resulting from the single European market and the benefits could be doubled if the regional integration also leads to new free trade agreements with key external partners (G. Lee \& Jeong, 2016). Advantage of AEC is less barriers that could make less cost to make businesses within countries in ASEAN. In contrary, disadvantage of AEC is resources transferring from host country will make domestic business decreases.

AEC have effect on stock market as well. Capital market in ASEAN countries have been integrated and driven by country-level economic situations (G. Lee \& Jeong, 2016). It leads to growing of foreign investment flows into ASEAN. Foreign investors, especially in develop countries, will send significant portion of their investment to emerging market, such as Southeast Asia (Niblock, 
Heng, \& Sloan, 2014). It leads to more foreign ownership in a country, either from other ASEAN countries or from outside ASEAN countries.

\section{ASEAN Corporate Governance Scorecard}

In 2009, the ASEAN Finance Ministers endorsed the ASEAN Capital Market Forum (ACMF) implementation plan to promote the development of an integrated capital market (ASEAN-CapitalMarket-Forum, 2015). This initiative is undertaken in parallel with the efforts to achieve convergence in ASEAN countries by 2015 as an economic community. Broadly, the ACMF implementation plan seeks to achieve the objectives of the ASEAN Economic Community aspirations through the following areas, which are creating an enabling environment for regional integration, creating the market infrastructure and regionally focused products and intermediaries, strengthening the implementation process, enhancing the visibility, integrity and branding of ASEAN as an asset class (ASEAN-Capital-Market-Forum, 2015).

The ASEAN corporate governance initiative comprising the ASEAN Corporate Governance Scorecard and the ranking of corporate governance of ASEAN public-listed firms among several regional initiatives under the ACMF (ASEAN-Capital-Market-Forum, 2015), started in early 2011 and is supported by the Asian Development Bank (2016a). The objectives of the Scorecard and the ranking exercise are to raise corporate governance standards and practices of ASEAN public-listed firms, showcase and enhance the visibility as well as investability of well-governed ASEAN publiclisted firms internationally, complement the other ACMF initiatives and promote ASEAN as an asset class (ASEAN-Capital-Market-Forum, 2015). The ASEAN Scorecard was developed based on national benchmarks such as the Organization for Economic Co-operation and Development (OECD) Principles of Corporate Governance, International Corporate Governance Network Principles, as well as best practices from the ASEAN and the world (Asian Development Bank, 2016). The Scorecard covers the following five areas of the OECD principles, which are rights of shareholders, equitable treatment of shareholders, role of stakeholders, disclosure and transparency, and responsibilities of the board (Asian-Development-Bank, 2016a). Assessment of each country is done by the Indonesian Institute for Corporate Directorship for Indonesia; the Minority Shareholder Watchdog Group for Malaysia; the Institute of Corporate Directors for Philippines; the Singapore Institute of Directors and Centre for Governance, Institutions and Organizations; as well as National University of Singapore Business School for Singapore; and the Thai Institute of Directors for Thailand (AsianDevelopment-Bank, 2016b).

The OECD Principles of Corporate Governance (OECD Principles) were used as the main benchmark for developing the Scorecard, given its global acceptance by policymakers, investors and other stakeholders (ASEAN-Capital-Market-Forum, 2015). Consequently, many of the items in the Scorecard may be best practices which go beyond the requirements of national legislation (ASEANCapital-Market-Forum, 2015). The experts drew references from the existing body of work and ranking initiatives in the region as well; including those by institutes of directors, shareholder associations and universities, to guide the initial inclusion of items in the Scorecard as well (ASEANCapital-Market-Forum, 2015).

The Scorecard covers the following five areas of the OECD Principles and two additional areas. Five areas of the OECD Principles carry a different weight based on the relative importance of the area. In 2012; area of "rights of shareholders" have 26 items of questions with 10 percent weighted of all five areas, area of "equitable treatment of shareholders" have 17 items of questions with 15 percent weighted of all five areas, area of "role of stakeholders" have 21 items of questions with 10 percent weighted of all five areas, area of "disclosures and transparency" have 42 items of questions with 25 percent weighted of all five areas, area of "responsibilities of the board" have 79 items of questions with 40 percent weighted of all five areas (Asian-Development-Bank, 2016b). In 2013; area of "rights of shareholders" have 25 items of questions with 10 percent weighted of all five areas, area of "equitable treatment of shareholders" have 17 items of questions with 15 percent 
weighted of all five areas, area of "role of stakeholders" have 21 items of questions with 10 percent weighted of all five areas, area of "disclosures and transparency" have 40 items of questions with 25 percent weighted of all five areas, area of "responsibilities of the board" have 76 items of questions with 40 percent weighted of all five areas (Asian-Development-Bank, 2016b). Each item carries one point. Some items may also provide for a "Not Applicable" option (ASEAN-Capital-MarketForum, 2015). Where a practice is mandated by laws, regulations or listing rules in a country, the firm is assumed to have adopted the practice unless there is evidence to the contrary (ASEANCapital-Market-Forum, 2015). In order to be awarded points, the disclosure by the firm must be sufficiently clear and complete. Overall score in each part is then computed by adding all the points in that part, adjusting for items which are not applicable to the firm (ASEAN-Capital-Market-Forum, 2015). The total score for a firm is then computed by weighting the scores for each part by the relative importance and totaling the weighted scores.

Items in area "right of shareholders" consist of basic of shareholders right; right to participate in decisions concerning fundamental corporate changes; right to participate effectively in and vote in general shareholder meetings and should be informed of the rules, including voting procedures that govern general shareholder meetings; markets for corporate control should be allowed to function in an efficient and transparent manner; the exercise of ownership rights by all shareholders, including institutional investors, should be facilitated (ASEAN-Capital-Market-Forum, 2015). Items in area "equitable treatment of shareholders" consist of shares and voting rights; notice of annual general meeting; insider trading and abusive self-dealing should be prohibited; related party transactions by directors and key executives; protecting minority shareholders from abusive actions (ASEAN-Capital-Market-Forum, 2015). Items in area "role of stakeholders" consist of the rights of stakeholders that are established by law or through mutual agreements are to be respected; where stakeholder interests are protected by law, stakeholders should have the opportunity to obtain effective redress for violation of their rights; Performance-enhancing mechanisms for employee participation should be permitted to develop; stakeholders including individual employee and their representative bodies, should be able to freely communicate their concerns about illegal or unethical practices to the board and their rights should not be compromised for doing this (ASEAN-CapitalMarket-Forum, 2015). Items in area "disclosure and transparency" consist of transparent ownership structure; quality of annual report; disclosure of related party transactions; directors and commissioners dealings in shares of the firm; external auditor and auditor report; medium of communications; timely filing/release of annual/financial reports; firm website; investors relation (ASEANCapital-Market-Forum, 2015). Items in area "responsibilities of the boards" consist of clearly defined board responsibilities and corporate governance policy; code of ethics or conduct; corporate vision/mission; board structure and composition; skills and competencies; board chairman; board meetings and attendance; orientation programs for new directors; director training; access to information; nominating committee; board appointments and re-election; CEO/executive management appointments and performance; board appraisal; director appraisal; committee appraisal; remuneration committee/compensation committee; remuneration matters; audit committee; internal audit; risk oversight.

Two additional areas are bonuses and penalties; contains 34 bonus and penalty items collectively, each with a different number of points (ASEAN-Capital-Market-Forum, 2015). The bonus and penalty items are designed to enhance the robustness of the Scorecard in assessing the extent to which firms apply the spirit of good corporate governance (ASEAN-Capital-Market-Forum, 2015). The bonus items are to recognize firms which go beyond items in five areas of OECD principles by adopting other emerging good practices (ASEAN-Capital-Market-Forum, 2015). The penalty items are designed to downgrade firms with poor governance practices which are not reflected in their scores for five areas of OECD principles, such as being sanctioned by regulators for breaches of listing rules (ASEAN-Capital-Market-Forum, 2015). The total bonus and penalty points are added to or subtracted from the total score in total scores for five areas of OECD principles to give the final 
score for the firm (ASEAN-Capital-Market-Forum, 2015). In 2012, there are 11 items of bonus with 23 maximum additional points and 23 items of penalty with 90 maximum subtraction points (AsianDevelopment-Bank, 2016b). In 2013, there are 9 items of bonus with 42 maximum additional points and 21 items of penalty with 53 maximum subtraction points (Asian-Development-Bank, 2016b).

The Scorecard was reviewed on an item-by-item basis against the OECD Principles, other international corporate governance principles and practices recommended by bodies such as the World Bank, International Corporate Governance Network (ICGN), Asian Corporate Governance Association (ACGA) and selected codes of corporate governance (ASEAN-Capital-Market-Forum, 2015). The Scorecard was put through a validation process by applying it to a sample of firms in each country to ensure that the wording of the items in the Scorecard is widely comprehensible and universally applicable to the extent possible (ASEAN-Capital-Market-Forum, 2015). The validation process also sought to identify the sources of information for the Scorecard items and any laws, regulations and listing rules applicable to each item for each country (ASEAN-Capital-MarketForum, 2015). The scorecard was also put through a peer-review exercise to ensure that there will be no discrepancies in the standard of assessment applied by each of the experts (ASEAN-CapitalMarket-Forum, 2015).

Important note that have to be seen by user of ASEAN corporate governance scorecard is accessibility of information in implementation of ASEAN corporate governance scorecard (ASEANCapital-Market-Forum, 2015). The assessment of listed firms by way of the Scorecard relies primarily on information contained in annual reports and firm websites (ASEAN-Capital-Market-Forum, 2015). Other sources of information include firm announcements, circulars, articles of association, minutes of shareholders' meetings, corporate governance policies, codes of conduct, and sustainability reports (ASEAN-Capital-Market-Forum, 2015). Only information which is publicly available and which is easily accessible and understood used in the assessment. To be given points in the Scorecard, disclosure must be unambiguous and sufficiently complete. To be assessed and ranked, most of this information should be in English (ASEAN-Capital-Market-Forum, 2015).

The Scorecard and methodology will be reviewed periodically, and if necessary, changes will be made to reflect new developments in corporate governance (ASEAN-Capital-Market-Forum, 2015). As with any corporate governance assessment based on publicly available information, there are inherent limitations in the Scorecard and ranking of listed firms. First, as the methodology relies on public information, only corporate governance policies and practices which are publicly disclosed are captured in the assessment (ASEAN-Capital-Market-Forum, 2015). Second, firms which disclose certain corporate governance practices may not be applying those practices or may only be applying them in form rather than in substance (ASEAN-Capital-Market-Forum, 2015). Third, although there are items dealing with the conduct of directors, management and employees of firms; the Scorecard is not specifically designed to assess the ethical behavior of those responsible for the stewardship of the firms (ASEAN-Capital-Market-Forum, 2015). Fourth, although good corporate governance should improve the long-term value of firms, no assertion is made about links between the corporate governance scores and the ranking of the firms with its financial performance (ASEAN-CapitalMarket-Forum, 2015).

\section{Corporate Governance, Foreign Ownership and Firm Value}

In terms of agency theory, management (agent) have a contract with owner (principal) which is delegating of authority from owner to management to manage firm based on owner interests. Interest of owner is wealth of themselves. In stock market context, shareholders wealth is the purpose of agency relationship as well as indicator of firm value. Firm value could be increased if shareholders have better support and management monitoring. Type of ownership is important to determine if management is working follow shareholders interest.

Foreign shareholder is one type of ownership. Foreign shareholder is shareholder of firm of across country. Foreign shareholders could rise by share traded in capital market by individual or 
institutional investor. Foreign shareholders could rise by establishment of subsidiary by home country's firm as foreign or multinational firm in host country as well. Foreign shareholders were risen by share traded in capital market by individual investor is foreign individual shareholders. In case of foreign or multinational firm in host country, foreign firm owned by firm from home country could be categorized as firm owned by foreign institutional shareholders (Rasiah \& Malakolunthu, 2009). Foreign institutional shareholders could be as foreign institutional investor that owns domestic firm.

Foreign shareholder is one type of shareholders that have effect on firm value. There are arguments said that foreign ownership have positive effect with firm value, while others predict negative effect; each theory have conditions under which its arguments held (S. Lee, Kim, \& DavidsonIII, 2015). Firm with foreign ownership have competitive advantages. Internalization theory said that foreign institutional shareholders enhances firm value by developing new markets for its assets from abroad (Gande, Schenzler, \& Senbet, 2009); such as superior research and development of marketing production capabilities and consumer goodwill (S. Lee et al., 2015), higher labor productivity, wages, export, technological intensities (Rasiah \& Malakolunthu, 2009; Wei et al., 2005) and international manager talents (Wei et al., 2005) that have been brought from home country. Those components are unique competitive advantages that could not easily enhanced by domestic firm owned by domestic shareholders. By implementing business standard of foreign institutional shareholders in home country and selection of international manager talents, foreign firm could enjoy those competitive advantages. Superior research and development of marketing production capabilities and consumer goodwill will increases revenues as well as earnings. Higher labor productivity, wages, export, technological intensities and international manager talents will improve firm performance as well as earnings. Higher earnings will leads to higher dividend and/or stock price as indicator of higher shareholders wealth and firm value. Previous research found that consumer goodwill (Fang, Palmatier, \& Steenkamp, 2008) and technological investment (Mithas \& Rust, 2016) could increases firm value through improvement of firm performance.

Either as individual or institution, foreign ownership have more financial and business advantages as well; such as open accesses of international capital market and hard currency (Wei et al., 2005), international diversification of earnings and decreasing of the variability of cash flows and bankruptcy costs (Gurunlu \& Gursoy, 2010); than domestic shareholders. Foreign shareholders could establish new channel of market share and funding resources across country (Gurunlu \& Gursoy, 2010); since foreign shareholders have more business information in home country than domestic shareholders. Foreign shareholders could make management to diversify market share, and generates more earnings as well as decrease the variability of cash flows. Foreign shareholders could raise fund in low cost of capital and low risk from another investor and creditors from other countries if cost of domestic capital is high, and could reduce bankruptcy costs. By decision making of new market and low risk financing policies in shareholders general meeting, foreign shareholder could increases revenues, as well as earnings, with low cost of capital and leads to firm value increasing. Foreign shareholders have better monitoring of management as well, than domestic shareholders. Foreign shareholders is more independent than domestic shareholders (Ahmed \& Iwasaki, 2015), in terms of differences nationality between domestic management and foreign shareholders. Better monitoring of management makes management have good performance and leads to firm value increasing (Ahmed \& Iwasaki, 2015).

In the other hand, foreign ownership could reduce firm value as well. In international level, imperfections of global market support this argument, because it is difficult to optimally diversify their businesses internationally due to such barriers as institutional restrictions on overseas capital flows and information asymmetries (S. Lee et al., 2015). It leads to bigger cost of foreign capital structure (Eun \& Janakiramanan, 1998), and will decrease profitability. In addition, there is lack of compatible of development of competitive advantages brought from home country, such as technological investment. Mithas \& Rust (2016) stated that new technological investment have risks such as firms may not be able to realize complex interrelationships among information technology 
systems, get locked into poor and incompatible systems and may suffer from information overload, leading to reduced learning. It will be able to get benefits of international diversification if global market is sufficiently integrated.

In firm level, manager factor could be a reason why foreign ownership reduces firm value. Foreign manager could improve information asymmetric as well, because of differences of language and geographical aspect between home country and host country. In multinational firm context, it is hard for foreign shareholders to monitors managerial decision making because of complexity of corporate structure with many foreign subsidiaries across country (S. Lee et al., 2015). Not only foreign manager have adaptation difficulty in domestic environment, but domestic manager as well have adaptation difficulty in firm where foreign shareholders have brought foreign atmosphere in some business activities. Goyer \& Jung (2011) found that social capital domestic CEO could reduce foreign ownership.

This research will analyze two of contrast arguments about effect of foreign ownership and firm value with consideration of country level, especially in ASEAN. It is important because ASEAN Economic Community have been established and will affect barriers between countries as restrictions effect of foreign shareholder to increase firm value.

Inconsistency of foreign ownership effects on firm value depends on corporate governance. Corporate governance is the key of monitoring mechanism to create value of firm. Man \& Wong (2013) stated that one of monitoring mechanisms is shareholders structure, includes foreign shareholders, while the other is shareholders protection. It shows that role of shareholders will have no effect on firm value if their rights do not supported by condition of good governance by firm. One of measurement of corporate governance, especially in ASEAN countries, is ASEAN corporate governance scorecard. ASEAN corporate governance scorecard shows corporate governance practices in areas of rights of shareholders, equitable treatment of shareholders, role of stakeholders, disclosure and transparency, and responsibilities of the board (Asian-Development-Bank, 2016a).

Area of rights of shareholders and area of equitable treatment of shareholders ensures clear voting right, decision making process, approve of board selection, voting class of shares, and conflict of interests (Asian-Development-Bank, 2016a). Both areas of rights of shareholders and equitable treatment of shareholders make sure that foreign ownership could uses their rights to contribute in decision-making of competitive advantages increasing (eg. Fang et al., 2008; Gande et al., 2009; Gurunlu and Gursoy, 2010; Lee, Kim, et al., 2015; Mithas and Rust, 2016; Rasiah and Malakolunthu, 2009; Wei et al., 2005), monitoring of management (Ahmed \& Iwasaki, 2015), as well as picture of reducing entrenchment effect of majority shareholders (Zerni, Kallunki, \& Nilsson, 2010) if foreign shareholders act as minority shareholders. Another evaluation such as whether there is any disclosure in English language (Asian-Development-Bank, 2016a), so foreign shareholders have low information asymmetric. Shareholders protection is the key of good corporate governance to improve role of shareholders (Maher \& Andersson, 1999; Man \& Wong, 2013).

Area of role of stakeholders ensures activities related to customer welfare; communities; creditors' rights; environmental sustainability; and employee safety, health, and welfare (AsianDevelopment-Bank, 2016a). Corporate governance area of role of stakeholders makes sure role of foreign shareholders to improves decision-making process related to consumer goodwill (S. Lee et al., 2015), higher labor productivity and wages (Rasiah \& Malakolunthu, 2009; Wei et al., 2005). This corporate governance area will support foreign shareholders decision making of foreign manager hiring, related to employee safety, health, and welfare.

Area of disclosure and transparency related to annual report; ensures disclosure of board activities, risk management, financial performance, auditing activities, whistle blowing policy, related party transaction, language availability and firms' website (Asian-Development-Bank, 2016a). Corporate governance area of disclosure and transparency will improves role of foreign shareholders by reducing information asymmetric (Madhani, 2016) because differences of domestic language and 
environment (Asian-Development-Bank, 2016a; S. Lee et al., 2015) as well as insider trading (Kho, Stulz, \& Warnock, 2009).

Area of responsibilities of the board ensures board and its committee activities to implement good corporate governance (Asian-Development-Bank, 2016a). Corporate governance area of responsibilities of the board improves foreign ownership in management monitoring. As proxy of shareholders in management daily activities, board have important role to make sure management acts in line with shareholders interests (Man \& Wong, 2013), including foreign shareholders interest.

Ha: Foreign ownership increases firm value, if firms' corporate governance scorecard is high.

\section{Methods}

\section{Sources of Data}

This research will examine moderating role of firms' corporate governance based on ASEAN corporate governance scorecard on effect of foreign ownership on firm value in five countries of ASEAN, which are Indonesia, Malaysia, Philippines, Singapore, and Thailand. These five countries have better access of data for this research than other countries of ASEAN. Data will be got from financial statement and ASEAN capital market forum website. Financial statement will be accessed from website of stock market of five countries.

\section{Research Sample}

Research sample is manufacture firms listed from 2012-2013 in stock market of five countries of ASEAN. Based on data available in World Bank (2016b), value added of manufacture industry (contributions of manufactures industry to economics) of Indonesia, Malaysia, Philippines, Singapore, Thailand, have been decrease from 2011-2013. Therefore, it is important to examine manufacture firms value related to foreign ownership as an effect of establishment of integrated stock market in ASEAN.

Firm with negative book value of equity will be excluded. Negative book value of equity indicates insufficiency of shareholder financing on firm activities, while this research will examines shareholders role on firm business activities. Insufficiency of shareholder financing means that there is lack of shareholders' role on firm business activities; because financing is dominated by creditors and indicates that role of creditors dominates on firm business activities. Negative book value of equity will make bias on Tobin's q measurement as well. The higher Tobin's Q indicates higher firm value. Negative book value of equity will leads to high Tobin's Q; not because of high market value of equity but because of high domination of debt in firm financing. In order to avoid bias on lack of shareholders' role on firm business activities and Tobin's q measurement, this research excludes firm with negative book value of equity. Based on table 1, there are 491 firms as research sample and 982 observations.

Table 1. Research Sample

\begin{tabular}{|c|c|c|c|}
\hline \multicolumn{2}{|c|}{ Firms in each country } & & \multirow{2}{*}{$\frac{\text { Tota }}{80}$} \\
\hline Indonesia & Manufacture firms listed 2012-2013 & 93 & \\
\hline & Incomplete data & (10) & \\
\hline & Negative Book Value of Equity & (3) & \\
\hline \multirow[t]{2}{*}{ Malaysia } & Manufacture firms listed 2012-2013 & 211 & 208 \\
\hline & Negative Book Value of Equity & (3) & \\
\hline Philippine & Manufacture firms listed 2012-2013 & 20 & 20 \\
\hline \multirow[t]{2}{*}{ Singapore } & Manufacture firms listed 2012-2013 & 120 & 117 \\
\hline & Negative Book Value of Equity & (3) & \\
\hline \multirow[t]{2}{*}{ Thailand } & Manufacture firms listed 2012-2013 & 71 & 66 \\
\hline & Data in local language & (5) & \\
\hline \multicolumn{2}{|c|}{ Number of Firms } & & 491 \\
\hline \multicolumn{2}{|c|}{ Number of Observations } & & 982 \\
\hline
\end{tabular}




\section{Variables}

Dependent variable is firm value. Firm value could seen by market share price as shareholders wealth. Firm value measured by Tobin's Q (Ahmed \& Iwasaki, 2015; Cremers \& Ferrel, 2014; Wei et al., 2005). Consideration of using Tobin's $Q$ follows a substantial literature on the association between firm value and various corporate arrangements, which extensively uses Tobin's $Q$ as a measure of firm value (Cremers \& Ferrel, 2014). Tobin's Q calculated by sum of book value of liabilities and market value of equity divided by book value of assets (Ahmed \& Iwasaki, 2015; Cremers \& Ferrel, 2014; Wei et al., 2005):

$$
\text { Tobin's } Q=\frac{\text { Book value of liabilities }+ \text { Market value of euqity }}{\text { Book value of assets }}
$$

Independent variable is foreign ownership. Foreign ownership is measured by number of shares held by foreign shareholders divided by number of outstanding shares (Ahmed \& Iwasaki, 2015; Eun \& Janakiramanan, 1998; Wei et al., 2005):

$$
\text { Foreign ownership }=\frac{\text { Number of firm shares held by foreign investor }}{\text { Number of outstanding firm shares }}
$$

Moderating variable is corporate governance level. It is dummy variable. Corporate governance measured by rank of score of ASEAN corporate governance scorecard of all listed firms in five capital markets of Thailand, Singapore, Philippines, Malaysia and Indonesia accessed in ASEAN corporate governance scorecard assessment report by Asian Development Bank (2016a, 2016b). It shows rank of average corporate governance score that covers area of rights of shareholders, equitable treatment of shareholders, role of stakeholders, disclosure and transparency, responsibilities of the board (ASEAN-Capital-Market-Forum, 2015). If firm includes in big 50 of the highest ASEAN corporate governance scorecard in its country, then it shows firm with the highest level of good corporate governance based on ASEAN evaluation standard. Score 1 if firm includes in big 50 of ASEAN corporate governance scorecard, 0 otherwise.

Control variables of firm level are managerial ownership, institutional ownership, leverage, firm size, and profitability. Managerial and institutional ownership are other ownership, beside foreign ownership, that have monitoring role in reducing agency conflict and increases firm value. Managerial ownership will be measured by proportion of shares owned by management, which is number of shares held by management divided by number of outstanding shares. Institutional ownership will be measured by proportion of shares owned by institution, which is number of shares held by institution divided by number of outstanding shares.

Consideration of leverage, size and profitability as control variables is triangle relationship of capital structure, firm size and performance determine firm value (Muzir, 2011). Leverage is the use of debt in capital structure. Debt is a capital source that increases the risk associated with future earnings, while firm with big size have big assets as resources to increase performance (Muzir, 2011). Leverage have negative effect on firm value. Firm size have positive effect on firm value. Leverage measured by debt to equity ratio (total of debt divided by total equity). Firm size measured by value of logarithm of total assets. Profitability is firm ability to generate profit by its assets. Profitability have positive effect on firm value. Profitability is measured with return on assets (net income after tax divided by total assets).

Control variable of stock exchange level of country is score of ASEAN Corporate Governance Scorecard. It will control big 50 of firms' rank of ASEAN Corporate Governance Scorecard that have possibility of different score range within 50 firms in each country. Even open market and integration have been established between countries in ASEAN, there are still unilateral liberalization initiatives in individual country (Yean \& Das, 2015). Each stock exchange of country have optimal standards of corporate governance. It will be measured by average country score of ASEAN Corporate Governance Scorecard (Asian-Development-Bank, 2016a, 2016b). 


\section{Analysis Model}

This research will run regression analysis as hypothesis test. In order to ensure the feasibility of regression model, this research will run classical assumption tests as preliminary test. Classical assumption tests are normality, heteroskedasticity, autocorrelation, and multicollinearity tests. Regression model is as followed:

$$
\begin{aligned}
& \text { Tobin's } Q_{i t}=\alpha+\beta 1 F O R_{i j t}+\beta 2 B_{1 G 50 C G_{i j t}}+\beta 3 F O R_{i j t} \text { BIG50CG } G_{i j t} \\
& +\beta 4 I N S T_{i j t}+\beta 5 M A N_{i j t}+\beta 6 R O A_{i j t}+\beta 7 S I Z E_{i j t} \\
& +\beta 8 D E R_{i j t}+\beta 9 A S E A N C G_{j t}
\end{aligned}
$$

where:

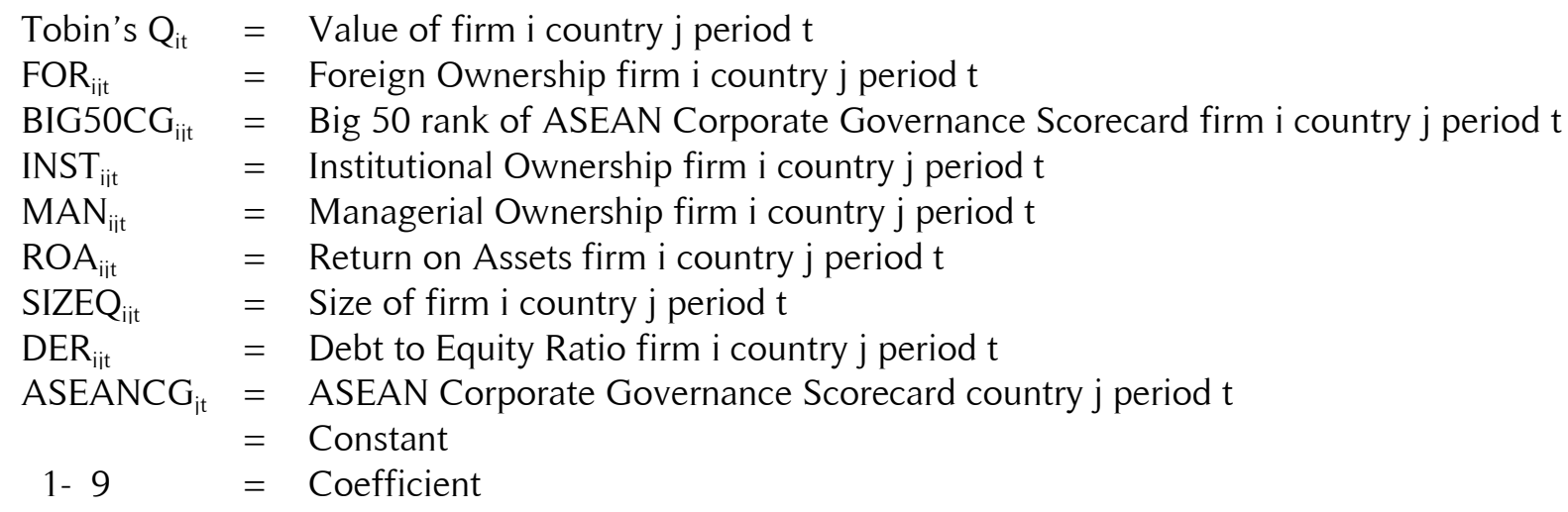

\section{Results and Discussion}

Descriptive Statistics

Table 2. Descriptive Statistics

\begin{tabular}{lllllllllll}
\hline Country & & Q & KPA & BIG50 & INST & MAN & SIZE & ROA & DER & CG \\
\hline Thailand & Mean & 1.4426 & 0.1163 & 0.1288 & 0.3494 & 0.1832 & 9.8345 & 0.0347 & 1.0391 & 71.5250 \\
& $\mathrm{~N}$ & 132 & 132 & 132 & 132 & 132 & 132 & 132 & 132 & 132 \\
& \% of Total N & 13.4 & 13.4 & 13.4 & 13.4 & 13.4 & 13.4 & 13.4 & 13.4 & 13.4 \\
\hline Singapore & Mean & 0.8073 & 0.1243 & 0.0128 & 0.3427 & 0.1661 & 8.1559 & 0.2192 & 0.8180 & 63.6750 \\
& $\mathrm{~N}$ & 234 & 234 & 234 & 234 & 234 & 234 & 234 & 234 & 234 \\
& \% of Total N & 23.8 & 23.8 & 23.8 & 23.8 & 23.8 & 23.8 & $23.8 \%$ & $23.8 \%$ & $23.8 \%$ \\
\hline Philippine & Mean & 2.3968 & 0.2251 & 0.2000 & 0.6088 & 0.0470 & 9.8080 & 0.0263 & 0.8929 & 53.4450 \\
& $\mathrm{~N}$ & 40 & 40 & 40 & 40 & 40 & 40 & 40 & 40 & 40 \\
& \% of Total N & 4.1 & 4.1 & 4.1 & 4.1 & 4.1 & 4.1 & $4.1 \%$ & $4.1 \%$ & $4.1 \%$ \\
\hline Malaysia & Mean & 1.2324 & 0.1112 & 0.0288 & 0.4436 & 0.1368 & 8.4451 & 0.0279 & 0.7603 & 66.9900 \\
& $\mathrm{~N}$ & 416 & 416 & 416 & 416 & 416 & 416 & 416 & 416 & 416 \\
& \% of Total N & 42.4 & 42.4 & 42.4 & 42.4 & 42.4 & 42.4 & 42.4 & 42.4 & 42.4 \\
\hline Indonesia & Mean & 1.8333 & 0.3510 & 0.0750 & 0.7164 & 0.0212 & 12.4692 & 0.1221 & 1.3584 & 48.9200 \\
& $\mathrm{~N}$ & 160 & 160 & 160 & 160 & 160 & 160 & 160 & 160 & 160 \\
& \% of Total N & 16.3 & 16.3 & 16.3 & 16.3 & 16.3 & 16.3 & 16.3 & 16.3 & 16.3 \\
\hline Total & Mean & 1.3047 & 0.1587 & 0.0530 & 0.4581 & 0.1276 & 9.2741 & 0.0897 & 0.9144 & 63.3137 \\
& $\mathrm{~N}$ & 982 & 982 & 982 & 982 & 982 & 982 & 982 & 982 & 982 \\
& \% of Total N & 100.0 & 100.0 & 100.0 & 100.0 & 100.0 & 100.0 & 100.0 & 100.0 & 100.0 \\
\hline
\end{tabular}

Based on table 2, mean of manufacture firm value in five countries of ASEAN is 1.3047. The highest mean of firm value is in Philippine with 2.3968, while the lowest in Singapore which is 0.8073. Mean value of foreign manufacture firm ownership in five countries of ASEAN is 0.1587. Indonesia have the highest mean value of foreign ownership with 0.3510 , while Malaysia have the lowest mean value of foreign ownership with 0.1102. On average, corporate governance scorecard in five countries of ASEAN is 1.3923. Indonesia have the lowest corporate governance scorecard with mean value 48.9200, while Thailand have the highest corporate governance scorecard with mean value 71.5250 . 
Table 3. Firms in Big 50 ASEAN Corporate Governance Scorecard

\begin{tabular}{lcc}
\hline & Observation & Percentage (\%) \\
\hline Includes in Big 50 ASEAN Corporate Governance Scorecard & 52 & 5.3 \\
Does not includes in Big 50 ASEAN Corporate Governance Scorecard & 930 & 94.7 \\
Total & 982 & 100 \\
\hline
\end{tabular}

Based on table 3, number of sample which includes in rank of big 50 of ASEAN corporate governance scorecard from 2012-2013 are 52, or 5.3 percent of all 982 sample. Number of sample which does not include in rank of big 50 of ASEAN corporate governance scorecard from 20122013 are 930 , or 94.7 percent of all 982 sample.

\section{Preliminary Test}

Objective of preliminary test to make sure that regression model is feasible. Result of preliminary test is in table 4.

\begin{tabular}{llll}
\multicolumn{4}{c}{ Table 4. Preliminary } \\
\hline & Test & Result & \\
\hline Normality & Jarque-Bera: & & Notes \\
& $-\quad$ Before Transformation and Winsorized & Sig. $=0.000$ & Not distributed normally \\
& $-\quad$ After Transformation & Sig. $=0.000$ & Not distributed normally \\
& $-\quad$ After Winsorized & Sig. $=0.344$ & Distributed normally \\
Heteroskedasticity & Glejser & Sig. $=0.000$ & There is heteroskedasticity problem \\
Autocorrelation & Breusch-Godfrey Serial Correlation LM Test & Sig. $=0.835$ & Free of autocorrelation problem \\
Multicollinearity & VIF & VIF $<10$ & Free of multicollinearity problem \\
\hline
\end{tabular}

Based on table 4, significance value of normality test is 0.000 (significant in 1 percent), which is residual of this research is not distributed normally. This research run data transformation method as a treatment of this problem, which is variable Tobin's Q transformed in to logarithm natural. After data transformation, significance value of normality test is still 0.000 (significant in 1 percent), which is residual of this research is not distributed normally. Next treatment of this problem is winsorizing. After winsorizing, significance value of normality test is 0.344 (above significant level), means residual of this research is distributed normally. Autocorrelation test have significance value 0.835 (above significant level), which is free of autocorrelation problem. Multicollinearity test have VIF below 10, which is free of multicollinearity problem. Heteroskedasticity test have significance value 0.000 (significant in 1 percent), means this research have heteroskedasticity problem. Because of heteroskedasticity problem, this research will use white-regression test with heteroskedasticity condition.

\section{Hypothesis Test}

Table 5. White Regression Test

\begin{tabular}{lccc}
\hline Variable & Coefficient & t-Statistic & Significance \\
\hline FOR & -0.091659 & -0.865533 & 0.3870 \\
FOR_BIG50CG & 1.113405 & $1.997209 * *$ & 0.0461 \\
BIG50CG & 0.467365 & $3.019263 * * *$ & 0.0026 \\
INST & 0.387568 & $3.126123 * * *$ & 0.0018 \\
MAN & 0.545399 & $2.902404 * * *$ & 0.0038 \\
ROA & 0.013849 & $4.537698 * * *$ & 0.0000 \\
SIZE & 0.095067 & $4.585956 * * *$ & 0.0000 \\
DER & -0.015400 & -1.450293 & 0.1473 \\
ASEANCG & 0.003181 & 1.114106 & 0.2655 \\
Constant & -1.380852 & $-4.343253 * * *$ & 0.0000 \\
\hline Dependent Variable & Ln Q & & \\
F-Statistics & $21.40422 * * *$ & & \\
Adjusted R Squared & 0.157678 & & \\
\hline$* * *$ significant in 1 percent & & & \\
$* *$ significant in 5 percent & & & \\
\hline
\end{tabular}


Based on table 5, foreign ownership have coefficient value -0.091659. Significance value of foreign ownership is 0.3870 (above significant level). Foreign ownership have no effect on firm value. Interaction between foreign ownership and firm rank of big 50 ASEAN corporate governance scorecard have coefficient value 1.113405 and significant value 0.0461 (significant in 5 percent). It indicates that foreign ownership increases firm value, if corporate governance scorecard of firm is high. Research hypothesis is accepted.

Firm rank of big 50 ASEAN corporate governance scorecard have coefficient value 0.467365 and significant value 0.0026 (significant in 1 percent). Firm rank of big 50 ASEAN corporate governance scorecard have positive effect on firm value. Institutional ownership have coefficient value 0.387568 and significant value 0.0018 (significant in 1 percent). Institutional ownership have positive effect on firm value. Managerial ownership have coefficient value 0.545399 and significant value 0.0038 (significant in 1 percent). Managerial ownership have positive effect on firm value.

Return on assets have coefficient value 0.013849 and significant value 0.0000 (significant in 1 percent). Return on assets have positive effect on firm value. Size have coefficient value 0.095067 and significant value 0.0000 (significant in 1 percent). Firm size have positive effect on firm value. Debt to equity ratio have coefficient value -0.015400 and significant value 0.1473 (above significant level). Debt to equity ratio have no effect on firm value. ASEAN corporate governance scorecard have coefficient value 0.003181 and significant value 0.2655 (above significant level). ASEAN corporate governance scorecard in stock exchange of country level have no effect on firm value. Adjusted $\mathrm{R}$ squared is 0.157678 , it means that all independent variables in this research could explain firm value 15.7678 percent, while 84.2322 percent explanation of firm value comes from other variables that does not include in this research.

\section{Alternative Tests}

Table 6. Alternative Tests

\begin{tabular}{|c|c|c|c|c|c|}
\hline \multirow[b]{2}{*}{ Variable } & \multicolumn{5}{|c|}{ Coefficient } \\
\hline & $\begin{array}{l}\text { With All Con- } \\
\text { trol Variables }\end{array}$ & $\begin{array}{l}\text { Controlled by } \\
\text { Corporate } \\
\text { Governance }\end{array}$ & $\begin{array}{l}\text { Controlled by } \\
\text { Corporate Go- } \\
\text { vernance and } \\
\text { Firm Factors }\end{array}$ & $\begin{array}{l}\text { Controlled by } \\
\text { Corporate Go- } \\
\text { vernance and } \\
\text { Ownership } \\
\text { Factors }\end{array}$ & Notes \\
\hline FOR & -0.091659 & 0.127282 & -0.010390 & -0.022010 & \\
\hline FOR_BIG50CG & $1.113405^{* *}$ & $0.990555^{*}$ & $1.100030 * *$ & $1.041028 *$ & Consistent Result \\
\hline BIG50CG & $0.467365 * * *$ & $0.674987 * * *$ & $0.470242 * * *$ & $0.630594 * * *$ & \\
\hline INST & $0.387568 * * *$ & & & $0.498673 * * *$ & \\
\hline MAN & $0.545399 * * *$ & & & $0.527606 * * *$ & \\
\hline ROA & $0.013849 * * *$ & & $0.009468 * * *$ & & \\
\hline SIZE & $0.095067 * * *$ & & $0.103168 * * *$ & & \\
\hline DER & -0.015400 & & -0.018197 & & \\
\hline ASEANCG & 0.003181 & $-0.005911 * *$ & 0.003056 & $-0.004327 *$ & \\
\hline Constant & $-1.380852 * * *$ & 0.266308 & $-1.210919 * * *$ & $-0.104219 *$ & \\
\hline F-Statistics & $21.40422 * * *$ & $30.18183 * * *$ & $24.36823 * * *$ & $25.05859 * * *$ & \\
\hline $\begin{array}{l}\text { Adjusted R } \\
\text { Squared }\end{array}$ & 0.157678 & 0.106335 & 0.142915 & 0.128272 & \\
\hline \multicolumn{2}{|l|}{ Sig. of Jarque-Bera } & 0.260 & 0.205 & 0.933 & Fulfill normality assumption \\
\hline \multicolumn{2}{|l|}{ Sig. of Glejser } & $0.000 * * *$ & $0.000 * * *$ & $0.000 * * *$ & $\begin{array}{l}\text { Not fulfill heteroskedasticity } \\
\text { assumption }\end{array}$ \\
\hline \multicolumn{2}{|c|}{$\begin{array}{l}\text { Sig. of Breusch-Godfrey Serial } \\
\text { Correlation LM Test }\end{array}$} & 0.160 & 0.915 & 0.436 & $\begin{array}{l}\text { Fulfill autocorrelation as- } \\
\text { sumption }\end{array}$ \\
\hline \multicolumn{2}{|l|}{ VIF } & $<10$ & $<10$ & $<10$ & $\begin{array}{l}\text { Fulfill multicollinearity as- } \\
\text { sumption }\end{array}$ \\
\hline \multicolumn{6}{|c|}{$\begin{array}{l}\text { *** significant in } 1 \text { percent } \\
* * \text { significant in } 5 \text { percent } \\
* \text { significant in } 10 \text { percent } \\
\text { - use white regression test }\end{array}$} \\
\hline
\end{tabular}


In order to ensure consistencies of hypothesis test result, this research will make other scenarios if hypothesis test is run as other alternative tests. This research will run three alternative tests. First alternative is regression model with corporate governance as control variable. Second alternative is regression model with corporate governance and firm factors as control variables. Third alternative is regression model with corporate governance and ownership as control variables. Results of alternative tests are in table 6.

Based on table 6, variable of interaction between foreign ownership and firm rank of big 50 ASEAN corporate governance scorecard have coefficient value 0.990555 (significant in 10 percent) for regression model with corporate governance as control variable. Variable of interaction between foreign ownership and firm rank of big 50 ASEAN corporate governance scorecard have coefficient value 1.100030 (significant in 5 percent) for regression model with corporate governance and firm factors as control variables. Variable of interaction between foreign ownership and firm rank of big 50 ASEAN corporate governance scorecard have coefficient value 1.041028 (significant in 10 percent) for regression model with corporate governance and ownership as control variables. It shows that results of alternative tests are consistent with hypothesis test.

\section{Discussion}

Foreign shareholders have no effect on firm value. It indicates that foreign shareholders do not always increase firm value. This research is not in line with previous research that stated foreign shareholders could brings competitive advantage to the firm (eg. Gande et al., 2009; Gurunlu \& Gursoy, 2010; S. Lee et al., 2015; Rasiah \& Malakolunthu, 2009; Wei et al., 2005) and increases firm value. Internalization theory said that foreign institutional shareholders enhances firm value by developing new markets for its assets from abroad (Gande et al., 2009); such as superior research and development of marketing production capabilities and consumer goodwill (S. Lee et al., 2015), higher labor productivity, wages, export, technological intensities (Rasiah \& Malakolunthu, 2009; Wei et al., 2005) and international manager talents (Wei et al., 2005) that have been brought from home country. By implementing the business standard of foreign institutional shareholders in home country and selection of international manager talents, firm owned by foreign shareholders could enjoy those competitive advantages. Wei et al. (2005) and Gurunlu \& Gursoy (2010) stated that foreign ownership have financial and business advantages as well; such as open accesses of international capital market and hard currency, international diversification of earnings and decreasing of the variability of cash flows and bankruptcy costs; than domestic shareholders.

In the other hand, imperfections of global market argues that it is difficult to optimally diversify their businesses internationally due to such barriers as institutional restrictions on overseas capital flows and information asymmetries (S. Lee et al., 2015). It leads to bigger cost of foreign capital structure (Eun \& Janakiramanan, 1998). There is lack of compatible of development of competitive advantages brought from home country as well, such as technological investment. Mithas \& Rust (2016) stated that new technological investment have risks such as firms may not be able to realize complex interrelationships among information technology systems, get locked into poor and incompatible systems and may suffer from information overload, leading to reduced learning. It will be able to get benefits of international diversification if global market is sufficiently integrated. Foreign manager could improve information asymmetric as well, because of differences of language and geographical aspect between home country and host country. In multinational firm context, it is hard for foreign shareholders to monitor managerial decision because of complexity of corporate structure with many foreign subsidiaries across country (S. Lee et al., 2015). Not only foreign manager have adaptation difficulty in domestic environment, but domestic manager as well have adaptation difficulty in firm where foreign shareholders have brought foreign atmosphere in some business activities, for example, research by Goyer \& Jung (2011) found that social capital domestic CEO could reduce foreign ownership because of foreign atmosphere in some business activities. Those 
problems prevent foreign shareholders to implements competitive advantages that have been brought.

Variable interaction between big 50 rank of ASEAN corporate governance scorecard and foreign ownership have positive effect on firm value. It shows that foreign ownership have positive effect on firm value if rank of ASEAN corporate governance is high. Corporate governance could be solution for problems that prevent foreign shareholders to implements competitive advantages and leads to firm value increasing. It could be seen by the result that shows big 50 rank of ASEAN corporate governance scorecard have positive effect on firm value. Corporate governance is the key of monitoring mechanism to create value of firm (Man \& Wong, 2013). This result is in line with previous research that stated corporate governance mechanism could strengthens role of shareholders to monitors management, by ensures rights of shareholders (Man \& Wong, 2013), ensures equitable treatment of shareholders (Madhani, 2016; Man \& Wong, 2013; Zerni et al., 2010), ensures activities related to customer welfare; communities; creditors' rights; environmental sustainability; and employee safety, health, and welfare (Asian-Development-Bank, 2016a) to increases management performance (Man \& Wong, 2013), ensures disclosure and transparency (Man \& Wong, 2013) as well as responsibilities of the board (Man \& Wong, 2013).

Rights of shareholders and equitable treatment of shareholders ensures clear voting right, decision making process, approve of board selection, voting class of shares, and conflict of interests (Asian-Development-Bank, 2016a). Both areas of rights of shareholders and equitable treatment of shareholders makes sure that foreign ownership could uses their rights to contributes in decisionmaking of competitive advantages increasing (eg. Fang et al., 2008; Gande et al., 2009; Gurunlu \& Gursoy, 2010; S. Lee et al., 2015; Mithas \& Rust, 2016; Rasiah \& Malakolunthu, 2009; Wei et al., 2005), monitoring of management (Ahmed \& Iwasaki, 2015), as well as picture of reducing entrenchment effect of majority shareholders (Zerni et al., 2010) if foreign shareholders act as minority shareholders. Another evaluation such as is there any disclosure in English language (AsianDevelopment-Bank, 2016a), so foreign shareholders have low information asymmetric. Shareholders protection is the key of good corporate governance to improve role of shareholders (Maher \& Andersson, 1999; Man \& Wong, 2013).

Role of stakeholders ensures activities related to customer welfare; communities; creditors' rights; environmental sustainability; and employee safety, health, and welfare (Asian-DevelopmentBank, 2016a). Corporate governance area of role of stakeholders makes sure role of foreign shareholders to improves decision-making process related to consumer goodwill (S. Lee et al., 2015), higher labor productivity and wages (Rasiah \& Malakolunthu, 2009; Wei et al., 2005). This corporate governance area will support foreign shareholders decision making of foreign manager hiring, related to employee safety, health, and welfare.

Disclosure and transparency related to annual report; ensures disclosure of board activities, risk management, financial performance, auditing activities, whistle blowing policy, related party transaction, language availability and firms' website (Asian-Development-Bank, 2016a). Corporate governance area of disclosure and transparency will improves role of foreign shareholders by reducing information asymmetric (Madhani, 2016) because differences of domestic language and environment (Asian-Development-Bank, 2016a; S. Lee et al., 2015) as well as insider trading (Kho et al., 2009).

Responsibilities of the board ensures board and its committee activities to implement good corporate governance (Asian-Development-Bank, 2016a). Corporate governance area of responsibilities of the board improves foreign ownership in management monitoring. As proxy of shareholders in management daily activities, board have important role to make sure management acts in line with shareholders interests (Man \& Wong, 2013), including foreign shareholders interest.

Inconsistency of foreign ownership effects on firm value depends on corporate governance. Shareholders will have no effect on firm value if their rights does not support by condition of good governance by firm. High governance scorecard; in areas of rights of shareholders, equitable treatment of shareholders, role of stakeholders, disclosure and transparency, and responsibilities of the 
board; improving contribution of foreign shareholders in decision-making of competitive advantages increasing, improving monitoring of management, reducing entrenchment effect of majority shareholders, increases role of foreign ownership to improving decision-making process related to consumer goodwill and higher labor productivity and wages, reducing information asymmetric and insider trading, and have support by board roles as well.

Institutional ownership have positive effect on firm value. It indicates that institutional shareholders have better knowledge of firm business than individual shareholders, so that institutional shareholders could monitors management better than individual shareholders (Man \& Wong, 2013) and leads to firm performance and value increasing. Managerial ownership have positive effect on firm value. It indicates that there is interests alignment between management and owner and reduces agency conflict (Man \& Wong, 2013) and leads to firm value increasing.

Return on assets have positive effect on firm value. It indicates that profitable firm increases shareholders wealth as indicator of firm value (Muzir, 2011). Size have positive effect on firm value. It indicates that large firm have large resources to increases firm value (Muzir, 2011). Debt to equity ratio have no effect on firm value. It indicates that contrary effect happens, which are debt increasing could reduce firm value because of bigger bankruptcy cost, while certain level of debt increasing could increases firm value because of decreasing of tax expenses (Sutrisno, 2016).

ASEAN corporate governance in country's stock market level have no effect on firm value. It indicates that ASEAN corporate governance is picture of corporate governance of all listed firms in stock market, not manufacture firms only, so that ASEAN corporate governance have no effect on manufacture firms value in ASEAN.

\section{Conclusion}

Objective of this research is to examine moderating role of corporate governance on effect of foreign ownership on firm value in five ASEAN countries. Foreign ownership have no effect on firm value. It indicates that foreign shareholders do not always increase firm value, it depends on implementation of corporate governance. Corporate governance; as a function of shareholders protection, monitoring improvement, and transparency; support foreign shareholder role in firm value increasing. With good corporate governance in areas of rights of shareholders, equitable treatment of shareholders, role of stakeholders, disclosure and transparency, and responsibilities of the board; foreign ownership could maximizes increasing of competitive advantages that brought by foreign shareholders and management monitoring, and leads to better firm performance and firm value increasing.

\section{Implications}

This research have implication to management of firm, especially manufacture firm in ASEAN. Management could make firm policy about optimal foreign ownership structure as well as optimal corporate governance, so management could maximizes shareholders wealth by firm value increasing. This research have implication to stock investor as well. Investors, who have interest send their investment abroad especially in ASEAN, have to see condition of corporate governance of publiclisted firms, so investors wealth could be maximized.

\section{Limitations and Suggestions for Future Research}

This research is not considers effect of each area of ASEAN corporate governance scorecard as corporate governance implementation to support foreign shareholders role on firm value increasing, because of limitation access of data. Another limitation is this research only use manufacture firms as research sample. Suggestions for future research are consider score of each area of ASEAN corporate governance scorecard and use firms in other industry to examine effect of foreign ownership on firm value. 


\section{References}

Ahmed, A. S., \& Iwasaki, T. (2015). Foreign Ownership, Manager Monitoring, and Firm Value: Evidence from Japanese Firms. Working Paper. Texas A \& M University, USA, Kansai University, Japan.

ASEAN-Capital-Market-Forum. (2015). ASEAN Corporate Governance Scorecard. Malaysia: Secretariat of ASEAN Capital Market Forum.

Asian-Development-Bank. (2016a). ASEAN Corporate Governance Scorecard Country Reports and Assessments 2014. Philippines: Asian Development Bank.

Asian-Development-Bank. (2016b). ASEAN Corporate Governance Scorecard Country Reports and Assessments 2015. Philippines: Asian Development Bank.

Bell, R. G., Filatotchev, I., \& Aguilera, R. V. (2014). Corporate Governance and Investors' Perceptions of IPO Foreign Value: An Institutional Perspective. Academy of Management Journal, 57(1), 301-320.

Chari, A., Chen, W., \& Dominguez, K. M. E. (2012). Foreign Ownership and Firm Performance: Emerging Market Acquisitions in the United Stated. IMF Economic Review, 60(1), 1-42.

Chen, C. X., Lu, H., \& Sougiannis, T. (2012). The Agency Problem, Corporate Governance, and the Asymmetrical Behavior of Selling, General, and Administrative Costs. Contemporary Accounting Research, 29(1), 252-282.

Cheung, Y., Stouraitis, A., \& Tan, W. (2011). Corporate Governance, Investment, and Firm Valuation in Asian Emerging Markets. Journal of International Financial Management \& Accounting, 22(3), 246-273.

Cremers, M., \& Ferrel, A. (2014). Thirty Years of Shareholder Rights and Firm Value. The Journal of Finance, 69(3), 1167-1196. https://doi.org/10.1111/jofi.12138

Eun, C. S., \& Janakiramanan, S. (1998). International Ownership Structure and the Firm Value. Global Finance Journal, 9(2), 149-171.

Fang, E., Palmatier, R. W., \& Steenkamp, J. E. M. (2008). Effect of Service Transition Strategies on Firm Value. Journal of Marketing, 72(5), 1-14.

Forti, C. A. B., Tsang, C. Y., \& Peixoto, F. M. (2011). Stock Market Development: an Analysis from a Multilevel and Multi-country Perspective. Brazilian Administration Review, 8(4), 351-373.

Gande, A., Schenzler, C., \& Senbet, L. W. (2009). Valuation Effects of Global Diversification. Journal of International Business Studies, 40(9), 1515-1532.

Gilson, R. J., \& Whitehead, C. K. (2008). Deconstructing Equity: Public Ownership, Agency Cost, and Complete Capital Markets. Columbia Law Review, 108(1), 231-264.

Goyer, M., \& Jung, D. K. (2011). Diversity of Institutional Investors and Foreign Blockholdings in France: The Evolution of an Institutionally Hybrid Economy. Corporate Governance: An International Review, 1966), 562-584.

Guillen, M. F., \& Capron, L. (2016). State Capacity, Minority Shareholder Protections, and Stock Market Development. Administrative Science Quarterly, 61(1), 125-160.

Gurunlu, M., \& Gursoy, G. (2010). The Influence of Foreign Ownership on Capital Structure of Non-Financial Firms: Evidence from Istanbul Stock Exchange. IUP Journal of Corporate Governance, 9(4), 21-29. 
Jensen, M. C., \& Meckling, W. H. (1976). Theory of The Firm: Managerial Behaviour, Agency Cost and Ownership Structure. Journal of Financial Economics, 3(4), 305-360.

Kesten, J. (2010). Managerial Entrenchment and Shareholder Wealth Revisited: Theory and Evidence from a Recessionary Financial Market. BYU LAw Review, 5(4), 1609-1660. https://doi.org/10.2139/ssrn.1555856

Kho, B. C., Stulz, R. M., \& Warnock, F. E. (2009). Financial Globalization, Governance, and the Evolution of the Home Bias. Journal of Accounting Research, 47(2), 597-635.

Kim, B. (2011). Do Foreign Investors Encourage Value-Enhancing Corporate Risk Taking? Emerging Markets Finance \& Trade, 47(3), 88-110.

Lam, S. (1997). Control Versus Firm Value: The Impact of Restrictions of Foreign Ownership. Financial Management, 26(1), 48-61.

Lau, C. M., \& Bruton, G. D. (2008). FDI in China: What We Know and What We Need to Study Next. Academy of Management Perspectives, 22(4), 30-44.

Lee, G., \& Jeong, J. (2016). An Investigation of Global and Regional Integration of ASEAN Economic Community Stock Market: Dynamic Risk Decomposition Approach. Emerging Markets Finance \& Trade, 52(9), 2069-2086.

Lee, J., Park, J., \& Park, S. (2015). Revisiting CEO Power and Firm Value. Applied Economics Letters, 22(8), 597-602.

Lee, S., Kim, M., \& Davidson-III, W. N. (2015). Value Relevance of Multinationality: Evidence from Korean Firms. Journal of International Financial Management \& Accounting, 26(2), 111149.

Liu, Z. J. (2016). Effect of Earnings Management on Economic Value Added: A cross-country study. South African Journal of Business Management, 47(1), 29-36.

Madhani, P. M. (2016). The Relationship between Ownership Types and Corporate Governance and Disclosure Practices of Firms Listed on Indian Stock Exchange. IUP Journal of Corporate Governance, 15(1), 7-29.

Maher, M., \& Andersson, T. (1999). Corporate Governance Effects on Firm Performance and Economic Growth. In Tilburg University Law and Economics Conference. Eindhoven, Netherlands: Tilburg University.

Man, C., \& Wong, B. (2013). Corporate Governance And Earnings Management: A Survey Of Literature. The Journal of Applied Business Research, 29(2), 391-418.

Mithas, S., \& Rust, R. T. (2016). How Information Technology Strategy and Investments Influence Firm Performance: Conjecture and Empirical Evidence. MIS Quarterly, 4Q1), 223-245.

Muzir, E. (2011). Triangle Relationship among Firm Size, Capital Structure Choice and Financial Performance. Journal of Management Research, 11(2), 87-98.

Niblock, S. J., Heng, P., \& Sloan, K. (2014). Regional Stock Markets and the Economic Development of Southeast Asia. Asian-Pacific Economic Literature, 28(1), 47-59.

Nikomborirak, D. (2015). The ASEAN Economic Community (AEC): Myths and Realities. Asian Economic Papers, 14(2), 71-90.

Rasiah, R., \& Malakolunthu, A. (2009). Technological Intensities and Economic Performance: A Study of Foreign and Local Electronics Firms in Malaysia. Asia Pacific Business Review, 15(2), 181-197. 
Renders, A., \& Gaeremynck, A. (2012). Corporate Governance, Principal-Principal Agency Conflicts, and Firm Value in European Listed Companies. Corporate Governance: $A n$ International Review, 20(2), 125-143.

Shiri, M. M., Salehi, M., \& Radbon, A. (2016). A Study of Impact of Ownership Structure and Disclosure Quality on Information Asymmetry in Iran. VIKALPA The Journal for Decision Makers, 41(1), 51-60.

Sutrisno. (2016). Struktur Modal: Faktor Penentu dan Pengaruhnya pada Nilai Perusahaan [Capital Structure: Determining Factors and Its Effect on Firm Value]. Jurnal Siasat Bisnis, 26(1), 7989.

Tan, W., \& Ma, Z. (2016). Ownership, Internal Capital Market, and Financing Costs. Emerging Markets Finance \& Trade, 52(2), 1259-1278.

Viana, V., Sheng, H. H., \& Lora, M. I. (2010). How to Be a Foreign Investor in Brazil? The Effect of Ownership Structure and Business Groups on Firm Value. In Encontra da ANPAD 25-29 December. Rio de Janiero.

Wei, Z., Xie, F., \& Zhang, S. (2005). Ownership Structure and Firm Value in China's Privatized Firms: 1991-2001. Journal of Financial and Quantitative Analysis, 401), 87-108.

World-Bank. (2016a). Foreign direct investment, net inflows (BoP, current US\$). World Bank Group. Retrieved from http://data.worldbank.org/indicator/BX.KLT.DINV.CD.WD at $17^{\text {th }}$ January 2017

World-Bank. (2016b). Manufacturing, value added (\% of GDP). World Bank Group. Retrieved from http://data.worldbank.org/indicator/NV.IND.MANF.ZS at 17 ${ }^{\text {th }}$ January 2017

Yean, T. S., \& Das, S. B. (2015). The ASEAN Economic Community and Conflicting Domestic Interests: An Overview. Journal of Southeast Asian Economies, 32(2), 189-201.

Zerni, M., Kallunki, J. P., \& Nilsson, H. (2010). The Entrenchment Problem, Corporate Governance Mechanisms, and Firm Value. Contemporary Accounting Research, 27(4), 1169-1206.

Zhang, Y., \& Roelfsema, H. (2014). Globalization, Foreign Direct Investment, and Regional Innovation in China. Journal of International Commerce, Economics \& Policy, 5(3), 1-26. 